\title{
Symbolic Interpretation of the Image of Goethe's Faust in the Context of Heidegger's Notions "The Earth" and "The Sky"
}

\author{
Albina Sayapova \\ Doctor of Philology, Professor of the department of Russian literature and methodology of its teaching \\ Kazan (Volga Region) Federal University, 18 Kremlyovskaya str., Kazan, 420008, Russia, albina.sayapova@kpfu.ru
}

\section{Oksana Amurskaya}

Ph.D., Senior Lecturer of the Department of Germanic philology, Kazan (Volga Region) Federal University 18 Kremlyovskaya str., Kazan, 420008, Russia; oksana2181@mail.ru

\section{Doi:10.5901/mjss.2015.v6n6s5p43}

\section{Abstract}

\begin{abstract}
Hermeneutic acquisition of the ontological point of M. Heidegger's works allows us to comprehend the representation of Goethe's Faust in the light of Heidegger's notions "the earth" and "the sky". Thus we can define the image of Faust as a way of a Western personality who rationally came to terms with the mankind threat Gestell (enframing) of civilization and finally attempted to come to his natural self. The article deals with the symbolic interpretation of the representation of Goethe's Faust in the light of Heidegger's notions "the earth" and "the sky", which reveals the ontological point of the romantic binar opposition "the earth" - "the sky", specifying that a person is a universal essence (a "worldly character"), connected in his Being with the earth and the sky, he is a part of a whole and receives his sense in his existence. It is well known, that Heidegger applied to Goethe's theories, trying to solve ontological problems. Hermeneutic perception of Goethe's oeuvre in the light of Heidegger's pre-understanding, interpreted as a "poetic touch of truth", leads to conceptualization of Faust's way as a search for truth and the possibility of "returning home" (M. Heidegger).
\end{abstract}

Keywords: hermeneutics; the Truth of Being; the search for Truth; der Wesenblick (the point of Being)

\section{Introduction}

The main emphasis of this article will be put on the problem of an interpretation of Faust's path of life which is seen as his search for Truth and the possibility of returning to the origin of his natural self. The problem considered here is regarded in the context of Heideggerian notions "the earth" and "the sky", the issue of Faust's interpretation in the light of Heidegger's ontology has been touched upon before in our earlier discussions (Sayapova, 2014). A hermeneutic interpretation of the main character in the light of these binary notions allows us to reveal the essence in his ontology: a person is considered to be the matter in the world, in his being, connected with "the earth" and "the sky". He represents a part of the Whole and discovers his philosophical meaning in his own being.

The problem posed above is determined by Heideggerian interpretation of hermeneutics. According to M. Heidegger, "a living word is to reign over the chaos of Babel", thus art is regarded as poetry. Being the enlightenment philosopher, he introduces the concept of "artistic truth" (Heidegger, 2006, p.46), which being the essence of art, by Heidegger, represents the ontology of the word.

\subsection{Literature review}

To uphold the conception of the interpretation of Goethe's Faust in the light of Heidegger's notions "the earth" and "the sky" it is necessary to give the short overview of the studies devoted to the oeuvre of the German philosopher of the XX century Martin Heidegger (1889-1976), which our research is based on. The question under study has been widely discussed in the works by A.V. Mikhailov and V.V. Bibikhin (1993), who dealing with the original texts, interpreted the meaning in their commentaries and suggested a number of alternative, verbal variations of their interpretation.

Although a number of issues have been analyzed and discussed, much remains to be done in the field of the research of the correlation of Heidegger's philosophy and Goethe's poetry. As Heidegger himself stated in his letter to Jaspers (August 1949), "I admittedly still lack an adequate relationship to Goethe. That's a real shortcoming but only one 
of many" (Dye, 2009, p. 207). Determining Heidegger as one of the "Goethe's children", Ellis Dye stresses the deep and lasting impact of Goethe on his thought and language (Dye, 2009). Thus as we can conclude from Dye's observations quoted above that Heidegger was deeply interested in Goethe's oeuvre in the field of ontology, the latter serving as the source of the artistic confirmation of his main thesis in art. According to Heidegger, a hermeneutic interpretation of creativity always represents "the artistic truth" (Heidegger, 2006).

Before we start the interpretation of Faust's path of life as a search for Truth and the possibility of returning to his self, we need to point out that Heidegger in his view of a person as a bearer of Being applied the notions "the earth" and "the sky", borrowed from F. Hölderlin's poetry, who restored the Greek concepts "the earth" and "the sky" in their original meaning (cited in Mikhailov, 1993, p. 30). Thus Heidegger trying to find a solution to the ontological problems in art (the expression of openness of Truth by means of F. Hölderlin's poetry) refers to antiquity, Ellada, regarded as the initial source. His view reflects the dialectal laws of Heraclitus, expressed in his statement:

It shows itself only when it remains unconcealed (unentborgen) and unexplained (unerklart). The earth lets every intrusion into her shatter upon herself. [... ] Openly cleared as she herself, the earth appears only where she is kept in trust (gewahrt und bewahrt) as the essentially undisclosable, that retreats back before every disclosing, i. e. constantly holds itself occluded.. (Heidegger, 2006, p. 30-31).

Thus "it unfolds itself only when it remains un-unconcealed" (Heidegger, 2006, p.30): what unfolds is concealed. According to A.V. Mikhailov, who interpreted Heidegger's philosophy in his commentaries "...the Truth cannont be regarded as a message, a subject or Being itself, it represents a fulfillment, a performance acted out in the human world, which reveals and enlightens the Being. The Truth is openness, and the human being is the one who reveals the Being, enlightens it. Consequently what opens, that conceals; what stands outside, hides in the darkness. This can be applied to a person: he is open to the sky, but in fact he is open, being preserved and guarded by the earth, living under the shelter of his land. Thus the truth is rooted in life, in Being, in "the earth" and the truth can be revealed in its rootedness in the earthly matter. This is not surprising as it essentially involves the person as "the place in Being", thus is carried out "between the earth and the sky" (Mikhailov, 1993, p.23).

It is essential to point out that all Heidegger's works were focused on the conceptualization of Truth as transparency, as a gap in Being. Such conceptualization of Truth is attached to Art, according to Heidegger. This idea was put forward in his work "The origin of the work of Art", "The world is the openness of the wide paths of the simple and essential decisions in the destiny (Geschick) of a geschichtlichen people. The earth is the coming-forth, forced-to-nothing, of the steadily self-occluding and so sheltering (Bergenden). World and earth are essentially different from one another and yet never separated. The world grounds itself on earth, and earth towers up through the world" (Heidegger, 2006, p.49).

\subsection{Methodology and objectives}

The present paper aims to examine and investigate Heidegger's notions "the earth" and "the sky" in the light of the interpretation of Goethe's Faust. At present we do not set ourselves the aim to carry out the detailed philosophical analysis of the above mentioned concepts, but to establish certain correlation between Heidegger's philosophy and Goethe's poetry, and consequently to provide our own interpretation of Faust's life span in the light of Heidegger's ontology.

There are different approaches to the solution of this problem. The method proposed in this article is the detailed textual analysis of the selected fragments of Goethe's Faust that will allow us to provide the ontological interpretation of his oeuvre. We have applied the structural and the semantic analysis of the text in the context of the systematic structural approach to a literary work, which ultimately contributes to the solution of the posed problem.

\section{Results and Discussion}

For the purpose to obtain the objective results two translations of Goethe's Faust into English were selected for our analysis. One of them was performed by Bayard Taylor in original meters in 2005 (Goethe, 2005) and the second one by A.S. Kline in 2003 (Goethe, 2003), which includes line numbers and full stage directions. Thus we have applied the text from both parts of Faust in our research.

In order to test the hypothesis outlined above it is well to turn to the textual analysis of the selected fragments of Goethe's "Faust". As we shall see later, the word by Goethe, is regarded by Heidegger as a "poetic sketch", as it 
conducts the openness of Truth, of the Being. Goethe's Faust determines his "place in the world" in his search for himself in it, his essential Being.

The initial part of this work, the dialogue between Mephistopheles and the Lord (not yet Faust) in "Prologue in Heaven" is by all means essential in comprehension of the author's conception of Faust's representation. Mephistopheles who feels "no trepidation" about his bet (Goethe, 2005, p.22), will do his best to mislead Faust. He counts on Faust's burdened soul and on his awareness of the duality of his nature:

\author{
Half conscious of his frenzied, crazed unrest, \\ The fairest stars from Heaven he requireth, \\ From Earth the highest raptures and the best, \\ And all the Near and Far that he desireth \\ Fails to subdue the tumult of his breast (Goethe, 2005, p.21)
}

The Lord being "the gardener" knows, "even while [he] buds his tree", "both flower and fruit the future years adorning". He also knows, that although Faust is "still confused", He will soon "lead him to a clearer morning"(Goethe, 2005, p.21). The author, in our poinion, provides his reader with the key, that represents the point of the whole story: a human being in his search for truth has the right to be mistaken. Moreover, human faults are inevitable and even necessary in mankind's attainment of truth. The lines cited above contain one more point which we consider to be the most essential: Faust will not comprehend the truth by his mind, the Lord himself "leads him to a clearer morning". Thus the truth will enlighten him being a part of Eternal Femininity. And the Lord seems to know about it.

The first monologue of Faust (Part I, Scene I) apparently reveals his earthly aim - to reach a secret perchance", to comprehend the truth. Faust dwells upon his previous attempt to search for the truth in the world:

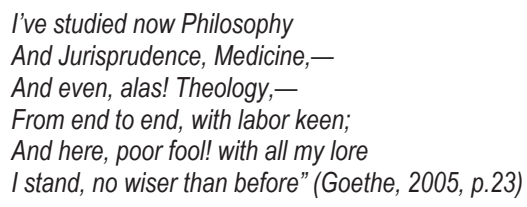

Thus in the fragment cites above Goethe through his character Faust transmits the idea, that consciousness and mind in their traditional rationalistic comprehension cannot provide a human being with the essential notions as the truth of Sein (Being). M. Heidegger develops this theory of the relationships of a person with the world in his work "Science and reflection":

Entrapping representation, which secures everything in that objectnesswhich is thus capable of being followed out, is the fundamental characteristic of the representing through which modern science corresponds to the real (Heidegger, 1977, p. 168)

Faust is trying to "seek assistance from Magic", opening access to the spiritual world to "to reach a secret perchance":

\author{
And thus the bitter task forego \\ Of saying the things I do not know,- \\ That I may detect the inmost force \\ Which binds the world, and guides its course; \\ Its germs, productive powers explore, \\ And rummage in empty words no more (Goethe, 2005, p.23)
}

Entering into a dialogue with the called Spirit of the Earth (the basis of which is the mythological image of Demogorgon (the Spirit of the Earth) as the original essence of all things, which spawned a three-part world, i.e. land, sky, sea, associated with what is commonly referred to as nature), Faust is again defeated:

I, image of the Godhead, who began-

Deeming Eternal Truth secure in nearness-

Ye choirs, have ye begun the sweet, consoling chant,

Which, through the night of Death, the angels ministrant

Sang, God's new Covenant repeating? (Goethe, 2005, p.30) 
Defeated by the Earthly Spirit, Faust considers suicide, but "gentle, powerful sounds of Heaven" stop him from transferring into other spheres:

Once Heavenly Love sent down a burning kiss

Upon my brow, in Sabbath silence holy;

And, filled with mystic presage, chimed the church-bell slowly,

And prayer dissolved me in a fervent bliss" (Goethe, 2005, p.31).

Faust, guarded this "celestial power", is back to life, to his earthly existence:

A sweet, uncomprehended yearning

Drove forth my feet through woods and meadows free,

And while a thousand tears were burning,

I felt a world arise for me (Goethe, 2005, p.31).

Faust exclaims:

My tears gush forth: the Earth takes back her child! (Goethe, 2005, p.31)

We consider this to be the first significant step in understanding the truth: it is in Being, in earthly life. Faust's soul seems to be ambivalent:

Two souls, alas! reside within my breast,

And each withdraws from, and repels, its brother.

One with tenacious organs holds in love

And clinging lust the world in its embraces;

The other strongly sweeps, this dust above,

Into the high ancestral spaces.

If there be airy spirits near,

'Twixt Heaven and Earth on potent errands fleeing,

Let them drop down the golden atmosphere,

And bear me forth to new and varied being! (Goethe, 2005, p.41)

Faust appears to be burdened by the breakaway duality of his soul and yet subservient to her dream to fly in the "unknown world".

However Goethe emphasizes that Faust as a person, initially feels the spiritual love to God, Nature, hence to a human being:

The wild desires no longer win us,

The deeds of passion cease to chain;

The love of Man revives within us,

The love of God revives again. (Goethe, 2005, p.43).

And he apparently rejects "that unknown world", offered by Mephistopheles:

The There my scruples naught increases.

When thou hast dashed this world to pieces,

"The other, then, its place may fill.

Here, on this earth, my pleasures have their sources;

Yon sun beholds my sorrows in his courses;

And when from these my life itself divorces,

Let happen all that can or will! (Goethe, 2005, p.57)

Faust's soul seems to cherish life on earth, the value of the present moment.

In the second part (Act V) Faust being in extremely old age, already anticipating the impending death, utters the following monologue:

But, at my back, this vexes so,

Proclaiming, with its jealous sound: 
My great estate is less than fine,

The old hut, all the trees around,

The crumbling chapel, are not mine. (Goethe,2003, p.501)

Thus Faust realizes, that "the old hut, all the trees around" contain essential content of Sein (Being), by definition of Heidegger, his hidden sources over which Faust as a person is not subservient.

And these hidden sources as essence of nature irresistibly attract Faust:

\author{
If I could banish Sorcery from my track, \\ Unlearn the magic-spells that draw me back, \\ And stand before you, Nature, as mere Man, \\ It would be worth the pain of being Human. \\ So was I, a seeker in the darkness, \\ Cursing both self and world, in wickedness. (Goethe,2003, p. 512)
}

And further he utters the following about the earthly force of gravity:

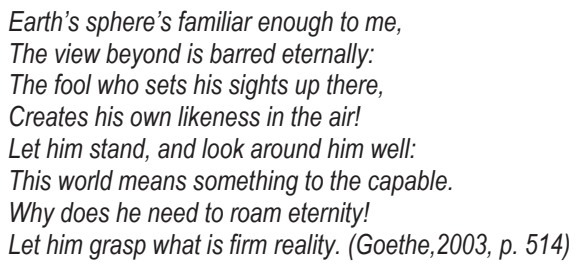

The monologue resonates according to the principle of circular composition with a monologue uttered in the first part (the third stage, a study of Faust).

Thus, the life span of Faust is between the sky and the earth as the search for truth reveals to him the essence of the earth, the right to return home to the natural, original sources.

Two feminine characters, Gretchen and Helen of Troy also represent the conception "the earth - the sky". Helen's love is the personification of ghostly antique beauty. Not coincidentally, Faust, admiring the beauty of Helen, exclaims:

This is a dream: time and place have fled (Goethe, 2003, p.428)

And once more together with Helen:

Is the sweetest bond a dream? (Goethe, 2003, p.446)

And Gretchen's earthly alive affection stays with Faust when "he's thrown off every bond / Of his old earthbound integument". Gretchen's soul is the one, that takes care of improving the soul of Faust:

Allow me to teach him, here (Goethe, 2003, p.538)

Speaking about Heidegger's notions "the earth" and "the sky", it is essential to emphasize the connection between the Heidegger's philosophy and scientific theories of Dao, in which these notions prove essential in the search for the human way to harmony and peace. Thus, Confucius, answering the question: "What was before the earth or sky began to be?" claimed, that in ancient times it was the same as now (, p.10). The earth and the sky are referred to in ontological meaning: "they let all human beings lead their own life" (Eno, 2010, p.10). "Emptiness is an essential expression of Being", according to Dao:

All between heaven and earth is like a great bellows--

Empty, yet it does not collapse,

The more it is moved the more it issues forth (Eno, 2010, p.11).

In the context mentioned above it is important to point out the correlation of Heidegger's being with the "emptiness" of Dao, which includes both the earth and the sky. This evidence can be supported by the dialogue between a Japanese professor D.T. Sudzuki with Heidegger. The Professor, referring to the lecture of a German philosopher What is 
Metaphysics?, containing a debate with nihilists on the topic of "nothingness", claims:

We marvel to this day how the Europeans could lapse into interpreting as nihilistic the nothingness of which you speak in that lecture. To us, emptiness is the loftiest name for what you mean to say with the world "Being" (Cited in Marra, 2010, p.283).

Heidegger, denying the nihilistic opposition "Nothing and Being" claims that "nothing" "is" this and that. But this means inevitable attachment of "Nothing" to "Being" (Heidegger 1978, p.73). As suggested by V.Bibikhin, in terms of philosophical jargon Heidegger treats emptiness as productive, "accommodating" openness (Bibikhin ,1993, p.13).

Heidegger's work A Dialogue on Language Between a Japanese and an Inquirer (cited in Marra, 2010) is an evidence of a tendency to find common types of thinking in Eastern and Western mentalities. In a dialogue between a Japanese professor Heidegger dwells upon the main subject of his philosophy - Sein (the "essential source") of human thought. The dialogue of two philosophers,-the speakers of two languages (the eastern and the western ones) deals with semantic features of single words, which express Sein (existential content) of human life. It leads to the idea, that Sein ("the essential source") in root of all languages may be the same", being a universal foundation in the ontological definition of human life. Heidegger's Being (Sein) dwelling in a "House of Being" is an indicator to the Sein ("essence") of language (cited in Marra, 2010). The ontological interpretation of a word as a part of a language allowed Heidegger to regard the mankind as a whole. According to one of the Russian orientalists, T.P.Grigoryeva, "Heidegger has mastered the language of east and West, he is a messenger of their adhesion- of two halves of the Unity" (Grigoryeva, 1992, p. 272).

Heidegger's understanding of it correlates with other western philosophers, including Goethe who he constantly applies to. An example of the linguistic Wesenblick ("essential foundations") may be an extract from Faust by Goethe [Part II, Act III] (Goethe, 2003), the scene in the inner court of the castle, the dialogue between Helen and Faust. Helen uses rhymed verse to answer Faust:

You will tell me how to speak with lovely art? (Goethe, 2003, p.426)

The Commentaries" to Faust tell us about the possible influence of Old Persian legend, which provided the first rhyme of the romance dialogue between the ruler Beramgur (Behramgur) and his servant Dilaram (the same plot was reflected in "West-East Divan") (Dmitrieva, 2006, p. 600). Gammer (1818) stated in his work, devoted to the history of Persian poetry:

\begin{abstract}
Historians name the poetry by Behramgur as the most ancient written manuscript of Persian poetry. He was a great ruler of Sanasid dynasty, who first talked rhymed. He was urged to it by his lover, a slave Dilaram, who expressed her love to him repeating his speech in dimensional and equally sounding words. That was the way the first poems might have emerged". The name Dilaram means "peace of heart". She tunes in the rhymed sounds of her lover and mastered the rhyme on her own (cited in Kessel', p. 50).
\end{abstract}

As suggested by the prominent Russian orientalist L.M. Kessel', "nascent love of Helen, is expressed in the transition of the antique measured form". So, in Kessel's view, "the German poetry correlates with the Persian royal legend". The point of this correlation is in "harmonization of words" in coordination in its "initial, musical" meaning (Kessel,1973, p.51).

\title{
3. Conclusion
}

Thus, we can conclude, that Wesenblick ("essential source") of languages is artistically expressed in Goethe's oeuvre. Goethe's "human solidarity" is equal to Wesenblick ("essential source") in Heidegger's works as human solidarity is expressed in Wesenblick ("essential source") of peoples' languages.

In the ontological interpretation Faust may be determined as Being-in-the-world (In-der-Welt-sein), applying Heidegger's terminology as he in his life-long search for truth ("a mysterious innerness of nature of nature") reveals the main law of human existence: a human being is a part of the Whole - Nature and is situated between "earth and sky" (Heidegger,2006), guarded by the earth and open to the sky.

Thus, hermeneutic conception of the Faust's life span between the earth and the sky leads to the conclusion, that Faust's character, in search for truth, which can last a lifetime, has passed a difficult contradictive way of the western type of thinking. In the final part of Faust (the monologue about the sense of eternal femininity) Goethe in our opinion transmits 
the idea, that the process of human cognition of the world is not framed by pure analysis of the features of the world. A spiritual cognition is implied here, beyond the rational understanding. Heidegger shares this theory, implying the essential content of Being inaccessible to science and to mind, in general. Goethe's creative intuition leads to the comprehension of the eastern type of consciousness and thinking (not coincidentally in search for Beauty he turns to Hellenic images). It is oriented at the comprehension of oneself as a part of a whole and consequently at a change of a person as a part of the world, according to the initial concept of Nature.

\section{References}

Bibikhin, V. (1993) Delo Khaydeggera [The case of Heidegger]. Translated from German by V. Bibikhin. Moskva: Respublika.

Dmitrieva, E.E. (2002) Kommentarii: Gete I.V. Stikhotvoreniya. Stradaniya yunogo Vertera. Faust [Commentaries: Goethe, I.W. Poems. The sorrows of Young Werther. Faust]. Moskva: AST-Olimp, pp: 483-623.

Dye, E., 2009. Sorge in Heidegger and in Goethe's Faust. Goethe Yearbook 16, pp. 207-218.

Eno, R., 2010. The Dao de jing. [e-book] Indiana University. Available at: Indiana University website <http://www.indiana.edu/ p374/ Daodejing.pdf> [Acessed 21 May 2014].

Goethe, J.W. von, 2005. Faust. Translated from German by Bayard Taylor [e-book] The World Publishing Company: Cleveland, the USA. Available at: The Project Gutenberg <http://www. gutenberg.org/files/14591/14591-h/14591-h.htm> [Acessed 21 May 2014].

Goethe, J.W. von, 2003. Faust. Translated from German by A.S.Kline [online] Available at: <http://www.poetryintranslation.com/PITBR/ German/Fausthome.htm> [Acessed 21 May 2014].

Grigoryeva, T.P. (1992) Dao i logos (vstrecha kul'tur) [Dao and Logos (the fusion of cultures)]. Moskva: Nauka, 424 p.

Heidegger, M., 1978. Letter on Humanism. In: D. F. Krell, ed. Basic Writings. London: Routledge, pp.213-265.

Heidegger, M., 1973. Art and Space: Man and Word. An International Philosophical Review 6 (1), pp: 3-8.

Heidegger, M., 2006. The Origin of the Work of Art, [online] Available at: <https://www.academia.edu/2083177/The_Origin_of_the_ Work_of_Art_by_Martin_Heidegger> [Acessed 21 May 2014].

Heidegger, $\bar{M}$., 1977. Science and Reflection. The question concerning technology [online] Available at: <http://ssbothwell.com/ documents/ebooksclub.org_The_Question_Concerning_Technology_and_Other_Essays.pdf> [Acessed 21 May 2014].

Kessel', L.M., 1973. Goethe and "Western-Eastern Divan". Moscow: Science, pp. 119.

Marra, M.F., 2010. A Dialogue on Language between a Japanese and an Inquirer. Kuki Shūzō's Version, [online] Available at: $<$ http://nirc.nanzan-u.ac.jp/nfile/2070> [Acessed 21 May 2014].

Mikhailov, A.V. (1993) Filosofiya proselka [Philosophy of the Country Road]. Moskva: Gnozis.

Sayapova, A.M., Arsenteva E.F., 2014. Life Science Journal. Onthological essence of Vyacheslav Ivanov's symbolic hermeneutics in the context of Martin Heidegger's philosophy, [online] Available at: < http://www.lifesciencesite.com/lsj/life1106/084_24757life110 614_560_564.pdf > [Acessed 21 May 2015].

Yates, Ch. (2011). The Poetic Imagination in Heidegger and Schelling (Doctoral dissertation). Retrieved from <http://dlib.bc.edu/ islandora/object/bc-ir:101901 > 